\title{
Quality of a Rural Destination: Visitor and Resident Approach
}

\author{
Kateřina Mlejnková \\ Mendel University in Brno, Czech Republic \\ katerina.mlejnkova@mendelu.cz \\ Tomáš Dania \\ Mendel University in Brno, Czech Republic \\ tomas.dania@mendelu.cz \\ Ida Rašovská \\ Mendel University in Brno, Czech Republic \\ ida.rasovska@mendelu.cz
}

Destination quality is a complex set of many factors. Methods of evaluating these factors are subject to continuous research. An evaluation of the visitors' and locals' satisfaction and using the results to manage the quality and sustainable development of the destination is a possible approach. This article applies importance-performance methodology to analyse a rural region in the Czech Republic. Using IPA analysis, the factors that most affect the satisfaction of visitors and residents are identified. The differences in the perceptions of visitors and residents are statistically significant, e.g., visitors consider the factors 'overcrowding' and 'friendly acceptance by locals' to be more important. At the same time, both groups have some awareness of the importance of sustainable tourism and the quality of services. The results indicate that in the region there are areas of improvement and performance, furthermore, they point out opportunities for the improvements mentioned. Moreover, the main difference between the performance (meaning the perceived level of quality of the service provided in the destination) and the importance of research factors has been determined. Based on the results, recommendations for destination management are formulated.

Keywords: quality, resident, visitor, rural destination, IPA

(cc)BY-SA https://doi.org/10.26493/2335-4194.14.87-99

\section{Introduction}

Tourism plays a big role in industry worldwide and it is one of the fastest-growing sectors. Usually, it is related to GNP, employment and other economic macro indicators (Politis et al., 2009). Travellers can choose from a wide variety of destinations, which implies that a destination is easily replaceable. For this reason, competitiveness between destinations is evident and the importance of tourism grows as well (Ayikoru, 2015).
For tourism destinations, competitiveness is essential, and each company or destination should find a better approach in competing with others by enhancing its products so that they gain a competitive advantage (Go \& Govers, 2000).

Quality is a factor strengthening competitiveness (Ennew et al., 1993) and influencing not only a positive perception of a service but also of an entire destination (Su et al., 2016; Weaver et al., 2007). UNW TO 
(n.d.a) defines quality as the result of a process that leads to meeting all legitimate needs, requirements and expectations of a customer concerning a service product, all this for an acceptable price in compliance with mutually accepted contract conditions and determining qualitative determinants, such as security, hygiene, availability of tourist services, transparency, authenticity and harmony of tourist activities with the human and natural environment. Determination and evaluation of destination quality is not easy due to its complexity, level of subjectivity when evaluating quality and the specific character of the services (Hudson, 2008). The quality of the destination also encompasses satisfaction of visitors, residents and other stakeholders. At the same time, emphasis is placed on the quality of the environment (European Commission, 2003). According to Ryglová et al. (2017), visitors' overall satisfaction is influenced by a set of factors constituting destination quality.

It can be stated that developing and maintaining the quality of the destination is a long-term process. Destination management often does not know visitors' important factors for and what assure their satisfaction in the destination (Rašovská et al., 2020). According to Caber et al. (2012), destination authorities and managers have to identify those destination attributes which are the most vital determining factors in customers' satisfaction. It is also advisable to examine the satisfaction of local residents. Therefore, the aim of this study is to perform an importance-performance analysis and provide valuable information for destination management.

This paper's objective is to evaluate destination quality by means of a complex set of factors applicable for destinations using importance-performance analysis (IPA), in the rural destination of the Moravian Karst in the Czech Republic. The research question, whether there is a difference in the perception of selected factors by destination between a group of visitors and residents, was formulated based on a literature review (Herrera et al., 2018). The analysis will be done separately for both residents and visitors and will clarify whether there are any differences between their perceptions of performance quality factors in the destination. The authors' aim is to determine differences in perception between tourists and residents, even in less-visited destinations that do not suffer from overtourism, and whether it is necessary to examine these groups separately. The outcome will be suggestions to boost destination quality, integrating both groups' requirements.

\section{Factors of Destination Quality}

The concept of destination is closely outlined as a target area that offers the attractiveness and infrastructure of tourism (Zelenka \& Pásková, 2012). Ryglová et al. (2015) indicate that it is appropriate to focus on detailed structure and analyse components which can be considered as determining for a destination's success. Goeldner and Ritchie (2014) define the destination as a geographically delimited area in which the visitor gets different experiences. For Bieger \& Beritelli (2012), the destination means a space, which is chosen by the visitor as a target of their journey. It must comprise of all necessary facilities for accommodation, boarding, and entertainment.

Buhalis (2003) defines five characteristic components of destination:

- Attractions (a primary offer of tourism that due to its amount, quality and attractiveness activates attendance, for instance, natural, culturalhistorical potential).

- Accessibility and ancillary services (a general infrastructure which enables access to the destination and travelling to the attractions in the destination; also, services used mainly by local inhabitants, such as telecommunication, medical and banking services).

- Amenities (superstructure and infrastructure of tourism that enable the stay in the destination and utilizing its attractions, for example, accommodation, sports- recreational, cultural-social facilities).

- Available packages (prepared products and product packages).

- Activities.

Middleton and Clarke (2001) add image and perception of the destination and price. According to some authors (Dortyol et al., 2014), individual factors 
can be grouped into categories, e.g. employees (friendliness, politeness, willingness), room equipment, food quality, material items, prices, transport, climate, hygiene and security. Milošević et al. (2016) add that within these factors, some others can be allocated, such as internet coverage, destination information, transport providers' quality, activity offer quality, medical assistance, local dwellers, destination cleanliness or level of pollution. As other authors confirm, a visitor's satisfaction with a destination is not only elicited by their experience with tourism services but also by other endogenous factors such as security, hospitality, the local population's friendliness, destination cleanliness, traffic infrastructure or the level of tourism management (Ashworth \& Page, 2011).

A destination is not just a product, but a whole system composed of several elements and relationships (Barrado, 2004). A destination strives for a complex offer of a service chain. The visitor then purchases and consumes these services in the destination. Therefore, it is possible to view a destination as a single product, consisting of many services offered to satisfy the visitors' expectations. The need to adopt quality-based strategies to develop customer service has been highlighted in service providers, where customer subjectivity plays a substantial role. It is because everyone perceives the service provided differently, and therefore, services are difficult to standardize (Caruana et al., 1999). Kotler and Keller (2007) describe service as an activity offered by one to another.

Marketing plans and promotional strategies (price, quality, image) are considered as key for destination competitiveness (Go \& Govers, 200o). Therefore, this planning process should be based on an analysis of a destination's competitive factors (Hassan, 2000). One of the possible approaches to destination quality research is to investigate visitors' satisfaction. A visitor's overall satisfaction is influenced by a set of factors constituting destination quality. These factors representing quality are the destination's primary potential (natural and cultural attractions), services provided, accessibility, destination management activities, and aspects of sustainability. At the same time, it is necessary to observe not just the functional but also the technical quality of services (Ryglová et al., 2017). In addition to determining the satisfaction of visitors, it is also important to reveal the perception of residents (Herrera et al., 2018). It is also crucial for the sustainable development of a destination to know the requirements of more than one stakeholder group (Herrera et al., 2018).

\section{Importance-Performance Analysis}

IPA is a commonly used research technique, which allows researchers and practitioners alike to understand customer satisfaction and to formulate strategies for improvements in products/services (Bi et al., 2019). This method was first introduced in the work of Martilla and James (1977) and is a basic diagnostic and decisive tool (Johns, 2001; Matzler et al., 2003) that facilitates the identification of factors with the highest priority for improvement (Sampson \& Showalter, 1999) and, according to Levenburg and Magal (2004), also the mobilization and development of the most required resources.

In one of the latest researches, Azzopardi and Nash (2013) subjected IPA to a critical analysis and, on the basis of analysing more than forty authors' works from the period of 1977-2007, they claim that despite its certain deficiencies, IPA is recommended and utilized in the area of tourist services as a method that is relatively easily applied in empirical studies. IPA and its use in literature focusing on hospitality and tourism were also studied by Lai and Hitchcock (2015), who revised analyzed nearly 60 articles and created a compact survey of the possibilities in applying IPA, without subjecting these utilizations to a critical analysis.

The authors Caber et al. (2012) use IPA for assessing destinations' attributes. The article shows empirically that market segments differ significantly within these two dimensions of the analysis, and thus it is suggested that IPA should be conducted on the segment rather than the aggregate level. Twenty quality factors have been assessed on a scale of five and a comparison of specific segments has been performed (German, British, Dutch and Russian respondents). The empirical basis of the article is laid by a sample of 821 customers in a Turkish destination. They found that IPA using an isoline of importance and performance instead of the traditional quadrant analysis yields better results and increases the diagnostic value of IPA. 
Using this tool, it is possible to identify the relative importance and performance of individual factors that have an impact on the observed quality. There are two possibilities for using the IPA analysis - data-centred (Ramakrishnan \& Usha, 2016) and scale-centred data (Tonge \& Moore, 2007). Median values which are used in the scale-centred IPA and are utilized in this article, according to some authors, tend to 'inflate' the results (Oh, 2001). When using a data-centred approach, the attributes are outlined according to their relative importance-performance (Boley et al., 2017).

\section{Methodology}

In this study, the quality of the rural area Moravian Karst in the Czech Republic and differences between the perception of visitors and residents are being investigated. The dominant attractions of this region are their interesting and valuable natural resources and scenery, caves and rock structures. Yearly, this region with fourteen caves welcomes about 360 thousand visitors (Ekolist, 2018). Since the 9os, the Moravian Karst has implemented some restrictions and only a certain number of visitors can enter. Therefore, it is not an overcrowded place. Additionally, according to the marketing strategy (Centrála cestovního ruchu - Jižní Morava, 2019), the Moravian Karst has the lowest visitor turnout and overnight stays in South Moravia.

The forms of tourism are the following: naturaloriented tourism, ecotourism, bicycle touring, hiking etc. (Pásková, 2009). The 20 factors of quality (Appendix 1) which were used in the questionnaire were formulated based on the previous researches about the quality components of the destination (Buhalis, 2003; Middleton \& Clarke, 2001; Ashworth \& Page, 2011; Ryglová et al., 2015; Milošević et al., 2016).

A questionnaire was self-administered in the region of the Moravian Karst and its surroundings in the Czech Republic using the tool quota sampling (gender, age) from August to October 2017. The data were conducted electronically on the internet and social networks, as well as through personal examination at the destination and placement at the information centres. The questionnaire was developed to understand the visitors' and residents' evaluation of the destination's quality. A range from 1 = 'not at all important/satisfied' to 5 = 'extremely important/satisfied' was used for the questions for importance/performance characteristics.

To ensure the representativeness of the questionnaire, it was necessary to determine the appropriate number of respondents. A statistical approach based on the following formula was used to determine the minimum number of respondents:

$$
n \geq \frac{z^{2} \times p \times q}{\Delta^{2}} .
$$

In this formula, $n$ is the minimum number of respondents, $z$ is the reliability coefficient, $p$ and $q$ are the numbers of respondents and the maximum permissible error (Kozel, 2006):

$$
278 \geq \frac{2^{2} \times 0.5 \times 0.5}{0,06^{2}}
$$

In the case of this questionnaire survey, the reliability coefficient was set at 2 , which corresponds to a $95 \%$ probability of assertion. According to the calculation, the minimum number of respondents is 278 . Thus, two quotas were set in advance for the selection of respondents and age and gender. According to data from the Czech Statistical Office on the age composition of the population as at 31 December 2016, a quota sample for age and sex was set.

A total of 408 respondents covering these characteristics (such as gender, age, education, and employment) were obtained, of which $50.3 \%$ were visitors and $49.7 \%$ residents. Nevertheless, a total of 94 failed to appropriately respond, leading to a total of 314 usable responses. The sample included an equal number of visitors $(50.3 \%)$ and residents (49.7\%). The detailed structure of respondents is shown in Table 1.

The data is equally distributed and accurately reflects the demographic development. Based on this, some parametric statistical methods can be used ( $t$ test). The testing was conducted at a $5 \%$ level of significance and different perceptions of factors between visitors and residents have been examined. The results in Table 2 show only statistically significant values and $p$-values.

To analyse data, Importance-performance analysis (IPA) was utilized. The analyses divide the attributes' performance and importance dimensions into four 
Table 1 Sample Characteristics

\begin{tabular}{llrr}
\hline Category & Item & Visitor & Resident \\
\hline Gender & Male & 46.8 & 51.3 \\
& Female & 53.2 & 48.7 \\
\hline Age & $18-23$ & 4.4 & 9.6 \\
& $24-30$ & 10.1 & 12.8 \\
& $31-40$ & 29.7 & 20.5 \\
& $41-50$ & 29.7 & 11.5 \\
& $51-60$ & 8.9 & 28.2 \\
& $61-70$ & 16.5 & 14.7 \\
& $>71$ & 0.6 & 2.6 \\
\hline Education & Trade school & 25.3 & 21.8 \\
& High school & 38 & 45.5 \\
& College graduate & 45.6 & 32.7 \\
\hline
\end{tabular}

Notes In percent.

Table 2 Statistically Significant Differences in the Perception of Factors between Residents and Visitors

\begin{tabular}{lllr}
\hline Factors & $(1)$ & $(2)$ \\
\hline F2 & Cultural and social attractions & Importance & 0.005 \\
& & Performance & 0.003 \\
\hline F3 & Accommodation & Importance & 0.002 \\
& & Performance & 0.006 \\
\hline F10 & Friendly acceptance & Importance & 0.002 \\
& by the locals & Performance & 0.003 \\
\hline F16 & Overcrowding of the desti- & Importance & 0.000 \\
& nation & Performance & 0.029 \\
\hline \multirow{2}{*}{ F18 } & Additional infrastructure & Importance & 0.044 \\
& & Performance & 0.004 \\
\hline \multirow{2}{*}{ F20 } & Certification of accommo- & Importance & 0.000 \\
& dation and food services & Performance & 0.025 \\
\hline
\end{tabular}

Notes Column headings are as follows: (1) perception of factors, (2) $p$-value (sig. 2-tailed).

quadrants which are easy to interpret and for acquiring practical suggestions (Dwyer et al., 2016). The four quadrants dividing quality factors are the following: 'Key Features/Keep Up the Good Work,' 'Concentrate here/Shortfalls,' 'Low priority factors' and 'Strategic/Possible Overkill.' The results of the IPA analysis are thus presented utilizing a two-dimensional graph with the average value of importance on the vertical axis and the average performance on the horizontal axis (Wong et al., 2011).

Factors represented in 'Key Features' have a very positive evaluation by clients and they have immense importance. Thus, destination management and local enterprises should keep delivering high-quality products. Factors representing 'Concentrate here' are characterized by very high importance but low performance. This means that even though the factors are important to the clients, the level of performance does not meet their requirements. Hence, it is crucial to pay more attention to these factors. Factors in 'Low priority' both show low importance and do not have a lot of impact on the performance of the destination under research. There is no need to invest either money or effort in improving these factors. The last quadrant, 'Possible overkill', characterizes the factors with low importance but high performance, which highlights the fact of excessive importance; however, visitors 'do not care' about the factor.

\section{Results}

The research aims to propose measures that will support the development of quality concerning the differences between the two groups. The suggestions are based on the IPA analysis and statistical data testing. The IPA analysis was compiled based on the average values of performance and importance of the research quality factors among visitors and residents. Performance, which was evaluated using respondents' satisfaction, has the average value of 3.97 for visitors and 3.79 for residents. Meanwhile, the significance of quality factors for the destination's visitors/residents is represented by the medium value of 3.91 and 3.72 , respectively. These two values create the centre of the coordinates that set up the four quadrants of IPA graph. Figure 1 captures the perception of 20 factors for the visitors (50.3\% of respondents), Figure 2 for residents (49.7\% of respondents).

The results show that the factors in quadrant Q1 (Key features) are not very different. Both visitors and residents consider $\mathrm{F} 13$ Level of personnel quality in tourism services, F14 Sense of security, F15 Destina- 


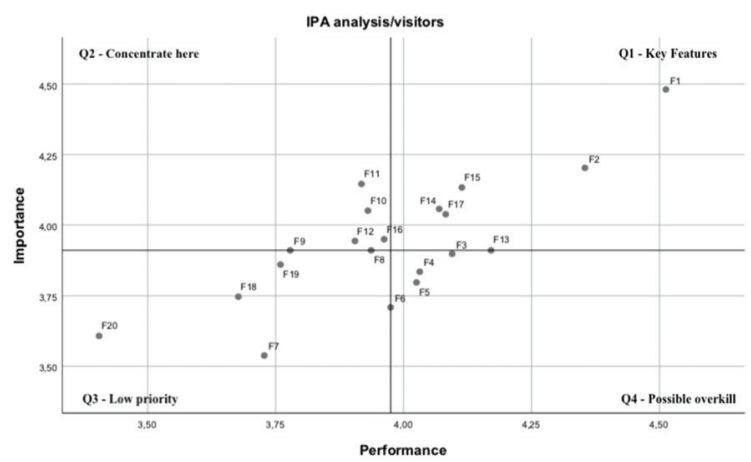

Figure 1 IPA Analysis from the Point of View of Visitors

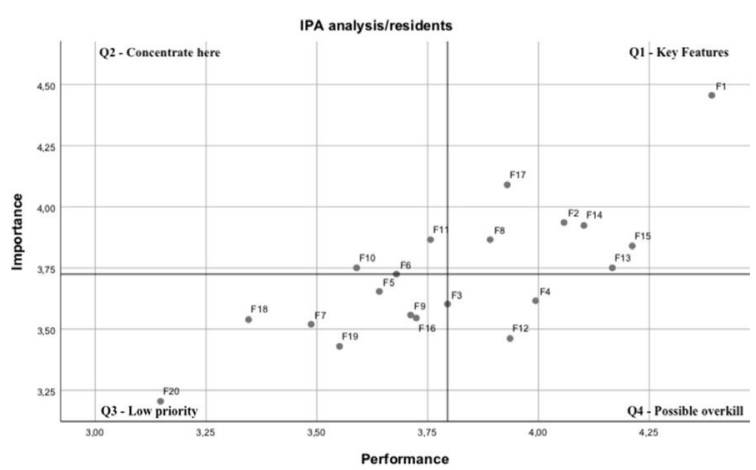

Figure 2 IPA Analysis from the Point of View of Residents

tion cleanliness and $\mathrm{F} 17$ Uniqueness of destination as factors with a high significance, while their qualitative level is positive enough. It is important to carry on improving the factors so that the performance does not decrease. F1 Natural attractions have the highest significance and highest performance for both groups of respondents. At the same time, F 2 Cultural and social attractions are evaluated with greater importance and perception for visitors. The only difference is within the $\mathrm{F} 8$ placement, Availability and quality of the information, which visitors placed in Q3, but residents in Q1.

The second quadrant, Q2 (Concentrate here), contains factors with low performance and great importance. This means that for visitors of the destination, factors such as F10 Friendly acceptance by the locals, F11 Image of the destination, F 12 Level of prices of services and goods at the destination and F16 Overcrowding of the destination are important, but the satisfaction of the level of quality is not enough. Thus, the aforementioned factors should be improved and receive priority attention. Both residents and visitors placed equally factors $\mathrm{F} 10$ and $\mathrm{F} 11$.

Another quadrant (Q3) consists of factors with low priority and low significance for visitors. It is not so important to pay too much attention to these factors, but the destination should keep in mind that some factors are changing, specifically those depending on demand, and therefore it is recommended not to underestimate them. Losing the level of quality of factors will lead to a negative overall satisfaction with the destination.

The last quadrant, Q4, is clarified as excess care of the factors which are less important for visitors/residents. As we can see in Figure 1 and Figure 2, only F 4 Food was placed by both categories of respondents to this quadrant, 'Possible Overkill.'

The biggest difference between visitors and residents is within factor F12 Level of prices of services and goods at the destination - while visitors consider this factor very important and place it in the quadrant Q2 - Concentrate here, for residents it belongs to the quadrant Possible Overkill. This detection makes sense as prices are a key factor in a decision whether to visit a destination or not.

An interesting finding is connected with factor F16 Overcrowding of the destination, where the residents consider this factor to have less importance and a lower level of perception, while for visitors, F16 is more important and perception of the quality level is higher. Nowadays, there are occurrences where masstourism is not perceived in the same way by the residents (for example, in Venice, Paris or Rome). In 1950, only 25 million tourists were travelling, in 2018 the number was 1.4 billion (Matulik, 2019). Rural areas are not particularly tourist-sought places and their residents do not meet the visitors as often as in cities. Visitors do visit the countryside and they may not even stop by in the village, or, they make one-day trips from major cities to rural destinations. This is confirmed by the questionnaire, where visitor-respondents state making mostly one-day (over 66\%), or weekend trips (2-3 days, over $22 \%$ ).

In addition to IPA analysis, independent $t$-tests 
were also conducted to verify the factors' perceptions of importance and performance. The Independent Samples $\mathrm{t}$ test is a commonly used test that determines whether there is a statistically significant difference between the means in two unrelated groups (Kim, 2015). Based on this it is possible to conclude whether differences in IPA analysis are statistically significant. Specifically, whether the position of factors in IPA graphs differs statistically in both axes $(y$ axis for importance and $x$-axis for performance). Statistically significant factors are listed in Table 2. Concerning IPA analysis, it can be said that the perception of factors included in quadrant Q1 does not differ remarkably between visitors and residents. The factor Cultural and social attractions (F 2$)$ is rated by visitors as more important ( $m=4.20$ vs. $m=3.94$ ) and more efficient ( $m=4.18$ vs. $m=3.97)$.

The factors in quadrant Q2 statistically differ in both axes. Especially, the factors Friendly acceptance by the locals (F1O) and Overcrowding of the destination (F16) are rated more important by visitors. There is a significant difference in the factor Accommodation ( $\mathrm{F} 3$ ) in quadrant Q3 and also in Additional infrastructure (F18), Respecting sustainable development of the destination (F19) and Certification of accommodation (F 2O) in quadrant Q4. While factors F 18 and F 2O, at a significance level of $0.1 \%$, are evaluated with a very low score, the differences between visitors and residents are significant. On average, visitors awarded the scale importance of the factor Certification of accommodation (F 2O) with 3.61 points and residents with 3.21 points. The same occurs with the factor Sustainable development (F19) - visitors rated it with 3.86 points and residents 3.43 points. Table 3 shows the differences in perceptions, where in general visitors rate more significantly than residents. The results show that the factors Natural attractiveness, Destination safety, Accessibility, and Quality and availability of information are important for both groups. Significant differences in the factors are cultural and social attractiveness, as well as accommodation, overcrowding, acceptance by locals, and social and experiential activities. Perceiving the importance of safety in the destination is most important for people aged 41-50, as well as its cleanliness.

\section{Discussion}

The research focuses on the differences in the perception of factors in a rura destination among visitors and residents. Based on the research question being confirmed, there are statistically significant differences in the perceptions of selected factors between the group of visitors and residents. According to our research results it is important to analyse visitors and residents separately even for destinations not yet suffering from over-tourism and irritation of local people. In most cases, visitors rate the factors higher on both axes (importance and performance) than residents. In addition, visitors may be more sensitive (Mok et al., 2001; Ryglová et al., 2017). Many aspects are ordinary for a resident, and after a while, they may stop perceiving them at all. However, knowledge of the aspects mentioned is very important, yet they create different perceptions (Stylidis et al., 2016). Hussain et al. (2019) pointed out that those residents who evaluate the environmental effects of tourism positively, give more noticeable support to tourism. Tourism can signify both positive and negative effects on environmental, socio-cultural and economic components for the locals. Puczko and Ratz (2000) append that although local people perceive some unfavourable impacts of tourism, they still support it. Considering the diverse impacts on the support of residents, Hussain et al. (2019) have found that perceived economic impact has the highest effect, after the socio-cultural and, lastly, the environmental effect. In this way, it is possible to increase visitors' satisfaction while not disturbing the lives of local inhabitants. When focusing on Q2 - Concentrate here, some perception differs more than in other quadrants. The factors Friendly acceptance by the locals (F10), Image of the destination (F11) and Overcrowding of the destination (F16) that belong to the second quadrant according to visitors, are linked with sustainable developments, which is a current topic (UNW TO, n.d.b).

One of the problems is mass tourism and overcrowding of a destination (Matulik, 2019). Nowadays, some tourist destinations are overcrowded and huge concentrations of visitors disrupt the lives of local people. Overcrowding is starting to be a hot topic of international tourism discussions. Furthermore, attitudes 
Table 3 Differences in Perception and Comparison between IPA and Statistical Testing

\begin{tabular}{|c|c|}
\hline between visitors and residents & $\begin{array}{l}\text { Comparison of differences in perception of factors } \\
\text { between IPA and statistical testing }\end{array}$ \\
\hline $\begin{array}{l}\text { the destination }(p=0.05) \text { are more important for visitors. } \\
\text { Cultural and social attractions, Friendly acceptance by the } \\
\text { locals }(p=0.05) \text { and Overcrowding of the destination ( } p \\
=0.001) \text { are perceived more significantly by visitors ( } p= \\
\text { 0.05). } \\
\text { Certification of accommodation facilities ( } p=0.001) \text { and } \\
\text { Respecting sustainable development ( } p=\text { o.0o1) are not } \\
\text { paid much attention to, they are relatively scored overall, } \\
\text { however, visitors still give more points to these factors. } \\
\text { Residents emphasize more the uniqueness of the destina- } \\
\text { tion, but this difference is not statistically significant }(p> \\
\text { o.05). }\end{array}$ & $\begin{array}{l}\text { In the IPA analysis, there is a difference in the factor F } 8 \\
\text { Availability and quality of destination information. This } \\
\text { factor belongs, according to the residents, to Q1, for visitors } \\
\text { to Q2 (on the line Q2\&Q3). } \\
\text { Factors F9 Information and communication prior to ar- } \\
\text { rival (visitors on the line Q2\&Q3 and residents Q3) and F12 } \\
\text { Level of prices of services (visitors Q2 and residents Q4) } \\
\text { also differ in the IPA analysis. } \\
\text { There is a further difference in F5 Social and experimental } \\
\text { events (Q4 visitors and Q3 residents). } \\
\text { The aforementioned factors are not statistically signifi- } \\
\text { cantly different, but in IPA analysis these factors belong to } \\
\text { different quadrants. }\end{array}$ \\
\hline
\end{tabular}

of local people to visitors are not very welcoming in overcrowded destinations. Nevertheless, the perception of mass tourism varies according to the type of destination, while this factor is perceived more in urban destinations. It also depends on the country and location (Kuščer \& Mihalič, 2019; Rasoolimanesh et al., 2017). A high concentration of people can cause pressure on infrastructure, changes of lifestyle, disturbance of overall well-being, price increase on the property market, growth of crime, noise, riots, etc. (Kuščer \& Mihalič, 2019; Milano et al., 2018). Similarly, in research focused on the centre of Prague, visitors and residents agreed that mass tourism changes the historical centre of the city (Simpson, 1999). The regional tourism organizations should deal with this kind of problem (Puczko \& Ratzs, 200o). In rural destinations, this problem is not so critical, which is also highlighted by the outcome of the present research. The reasons for visiting a rural destination are different from those for an urban destination (GarcíaHernández et al., 2017 Namberger et al., 2019; Ryglová et al., 2017). Visitors mostly travel with their families or friends and stay there for more than a day - usually a weekend, i.e. about 2-3 days, sometimes longer. It can therefore be assumed that visitors are not as concentrated in one place as in city centres. On the other hand, overcrowding can have a negative impact on factors in quadrant Q1 where it can negatively af- fect nature, the cultural environment and others (Hall, 2019).

Price rises are also related to tourism and high demand (Milano et al., 2018). According to the research, visitors rate prices as a more important factor than the locals do. The reason may be that the locals of the Moravian Karst do not visit tourist attractions. Due to the great interest, these attractions are often more expensive. Another reason may be that visitors travel to the destination with children, and the one-off expenses may therefore increase. A visitor-oriented factor, Friendly acceptance (F10) by the locals, is also worth mentioning. It was expected that the difference between the two groups would be large and it has been proven that the visitors evaluated the factor of friendly acceptance by locals much more significantly. Understandably, it is more difficult for a resident to value the environment in which they live. On the other hand, this factor belongs to the more important ones, which creates overall perception and positive emotions of destinations (Ashworth \& Page, 2011). Besides this, overcrowding of a destination is connected with these factors - a massive crowd of tourists creates a negative perception of tourism, which afterwards leads to residents' unfriendly behaviour, and the perception of safety or danger in the destination. Overcrowding and friendly acceptance by the locals are factors that are closely related to the overall quality of destina- 
tion (Ashworth \& Page, 2011). According to the results, people stay longer and they return to the countryside often. This gradually builds loyalty to the place and to the service provider, who apparently could be a local inhabitant.

Sustainability is a relatively common topic nowadays and many authors talk about it (Boley et al., 2017; Hall, 2019; Hassan, 2000). Yet, respondents do not pay too much attention according to the factor Respecting sustainable development. As mentioned above, sustainability is connected to the most important factors, such as protection of natural and cultural heritage or cleanliness in the destination (Hall, 2019). Puczko and Ratz (2000) determined that due to the tourism's development characteristics in the region, only some form of mass tourism can be maintained. The cleanliness of the destination is also significant for the visitors. The results show that the most important factor is natural and cultural attractions. Rural tourism is a certain escape from the big city. Following this, research shows that untouched scenery and cleanliness in a destination are crucial for respondents and that people look for a clean and undisturbed landscape. On the other hand, sustainability in tourism helps avoid overloading the destination, and aids in maintaining its quality (Hall, 2019; Hassan, 2000).

Nevertheless, certain regions in the Czech Republic are not so frequently visited, thus this factor is irrelevant for both visitors and residents. And perhaps the missing information about tourism and its negative consequences might influence this as well. The factor Certification of accommodation and food (F 2O) can also be influenced by lack of information as the respondents do not consider this factor important, either. At the same time, there is growing pressure for quality and certification in the Czech Republic (Jakšová, 2018). Although some factors are located in the same quadrant of the IPA graph, some statistically significant differences between visitor and resident ratings and vice versa have been proved. It is, therefore, appropriate to carry out additional testing to correctly interpret the IPA results. The $t$-test was chosen for this research because they revealed significant differences in IPA that are not so obvious at first sight. Nevertheless, it would not be necessary if two groups are not compared with each other. The advantage of this method is its simplicity and quick feasibility. When comparing multiple variables, it would make sense to also use MANOVA or ANOVA analysis.

\section{Conclusion}

The research aims to propose measures that will support the development of destination quality around the differences between the aforementioned groups. Based on individual IPA analyses, it can be stated that the most significant difference in perception lies in quadrant Q2 - Concentrate here. It is necessary to pay particular attention to the factor Overcrowding of the destination, as it may negatively affect other aspects of the destination. At the same time, there is little awareness of the linkages of sustainable tourism and the quality of services. It is, therefore, necessary to involve destination organizations and create a link between service providers and potential customers. Nonetheless, the local population should not be forgotten, as the attitude of the locals can determine the overall perception of the destination, and their attitude to tourism is directly related to overall visitors' satisfaction.

Considering the previous, we can conclude that there is space just for destination organizations, which could take a certain responsibility for quality and awareness (Dania et al., 2019; Go \& Govers, 2000). According to the research, destination management should analyse visitors and residents separately. If only the IPA analysis is used, the factors seem to be similar. Adding the $t$-test, it is shown that the differences are significant. Since tourism is a dynamically developing industry and visitors constantly increase their demands, it is, therefore, necessary to further create and maintain the attractiveness of the destination. It is necessary to proceed comprehensively and develop all the essential parameters of tourism (accommodation, catering, transport accessibility, cleanliness, etc.). Destination management should evolve tourism according to the principles of sustainable development and protect the negative impact of tourism on the environment as well as a negative impact on local people and on their cultural identity. Primarily, it is important to focus on the factors in quadrant $\mathrm{Q} 2$ because they can 
have both negative and positive effects on all other quadrants. Regarding this, it would be advisable to focus on tourism sustainability. Moreover, there should be a permanent dialogue between destination organizations, city authorities and local people. Speaking of sustainability, it is important to maintain the integrity of parks, the local economy and public transport (Milano et al., 2018). Nowadays, it is also possible to consider the involvement of smart technologies as it can facilitate communication with stakeholders as well as help maintain dialogue and education (Wang et al., 2016).

The present research was followed by an equal number of visitors (50.3\% of the total sample) and residents ( $49,7 \%$ of the total sample). Based on this it was possible to compare the perception of factors between visitors and residents. Regarding this, there should be some limits. It can be expected that people interested in this issue were more likely to participate in the research and their positive interest may subsequently cause a slight overestimation of the results. It is also advisable to point out the results of IPA analysis itself. Although the development of two separate IPA analyses has brought some new information, the results need to be treated with caution and analysed statistically as the individual analysis points out a higher difference. Only then can one claim that there is indeed a difference in perception. However, how apparent this difference is under real conditions is difficult to evaluate.

For any future research, it is advisable to conduct a similar survey in another rural destination and compare it with our results. At the moment, the results of the present study cannot be generalized. Moreover, it may be very difficult for respondents to evaluate the importance and performance at the same time, posing yet another potential limitation.

\section{References}

Ashworth, G., \& Page, S. J. (2011). Urban tourism research: Recent progress and current paradoxes. Tourism Management, 32(1), 1-15.

Ayikoru, M. (2015). Destination competitiveness challenges:

A Ugandan perspective. Tourism Management, 50, 142158.

Azzopardi, E., \& Nash, R. (2013). A critical evaluation of importance-performance analysis. Tourism Management, $35,222-233$.

Barrado, T. (2004). El concepto de destino turístico: Una aproximación geográfico-territorial. Estudios turísticos, 160, 45-68.

Bi, J. W., Liu, Y., Fan, Z. P., \& Zhang, J. (2019). Wisdom of crowds: Conducting importance-performance analysis (IPA) through online reviews. Tourism Management, 70 , $460-478$.

Bieger, T., \& Beritelli, P. (2012). Management von Destinationen. München Oldenbourg Verlag.

Boley, B. B., McGehee, N. G., \& Hammett, A. T. (2017). Importance-performance analysis (IPA) of sustainable tourism initiatives: The resident perspective. Tourism Management, 58, 66-77.

Buhalis, D. (2003). eTourism: Information technology for strategic tourism management. Pearson Education.

Caber, M., Albayrak, T., \& Matzler, K. (2012). Classification of the destination attributes in the content of competitiveness (by revised importance-performance analysis). Journal of Vacation Marketing, 18(1), 43-56.

Caruana, A., Pitt, L., \& Berthon, P. (1999). Excellence-market orientation link: Some consequences for service firms. Journal of Business Research, 44(1), 5-15.

Centrála cestovního ruchu - Jižní Morava. (2019). Marketingová strategie Jiřní Moravy: 2018-2020. https://www .ccrjm.cz/wp-content/uploads/2019/11/Marketingov $\% \mathrm{C}_{3} \% \mathrm{~A} 1$-strategie-Ji\%C5\%BEn\%C3\%AD-Moravy-2018 -2020.pdf

Dania, T., Mlejnková, K., \& Rašovská, I. (2019). Quality destination management. Acta Universitatis Agriculturae et Silviculturae Mendelianae Brunensis, 67(4), 1027-1037.

Dortyol, I. T., Varinli, I., \& Kitapci, O. (2014). How do international tourists perceive hotel quality? An exploratory study of service quality in Antalya tourism region. International Journal of Contemporary Hospitality Management, 26(3), 470-495.

Dwyer, L., Dragićević, V., Armenski, T., Mihalič, T., \& Knežević Cvelbar, L. (2016). Achieving destination competitiveness: An importance-performance analysis of Serbia. Current Issues in Tourism, 19(13), 1309-1336.

Ekolist. (2018, March 6). Návštěvnost jeskyní v Moravském krasu se loni zvýšila. Ekolist.cz. https://ekolist.cz/cz/ zpravodajstvi/zpravy/navstevnost-jeskyni-v-moravskem -krasu-se-loni-zvysila

Ennew, C. T., Reed, G. V., \& Binks, M. R. (1993). Importanceperformance analysis and the measurement of service quality. European Journal of Marketing, 27(2), 59-70.

European Commission. (2003). A manual for evaluating the 
quality performance of tourist destinations and services (Enterprise DG Publication). Office for Official Publications of the European Communities. https://ec.europa .eu/growth/content/manual-evaluating-quality -performance-tourist-destinations-and-services-o_en

García-Hernández, M., la Calle-Vaquero, D., \& Yubero, C. (2017). Cultural heritage and urban tourism: Historic city centres under pressure. Sustainability, 9(8), 1346. https://doi.org/10.3390/su9o81346

Go, F. M., \& Govers, R. (200o). Integrated quality management for tourist destinations: A European perspective on achieving competitiveness. Tourism Management, 21(1), 79-88.

Goeldner, C. R., \& Ritchie, J. R. B. (2014). Cestovní ruch: principy, př́klady, trendy. BizBooks.

Hall, C. M. (2019). Constructing sustainable tourism development: The 2030 agenda and the managerial ecology of sustainable tourism. Journal of Sustainable Tourism, 27(7), 1044-106o.

Hassan, S. S. (200o). Determinants of market competitiveness in an environmentally sustainable tourism industry. Journal of Travel Research, 38(3), 239-245.

Herrera, M. R. G., Sasidharan, V., Hernández, J. A. Á., \& Herrera, L. D. A. (2018). Quality and sustainability of tourism development in Copper Canyon, Mexico: Perceptions of community stakeholders and visitors. Tourism Management Perspectives, 27, 91-103.

Hudson, S. (2008). Tourism and hospitality marketing: A global perspective. Sage.

Hussain, K., Ali, F., Nair, P. K., Ragavan, N. A., \& Nair, V. (2019). Perceived impacts and residents' support for tourism development in Port Dickson, Malaysia. Turizam: medunarodni znanstveno-stručni časopis, 67(4), 351-364.

Jakšová, B. (2018). Destinační management v České republice: nový systém kategorizace a certifikace [Unublished diploma thesis]. Vysoká škola ekonomická v Praze.

Johns, N. (2001). Importance-performance analysis using the profile accumulation technique. Service Industries Journal, 21(3), 49-63.

Kim, T. K. (2015). T test as a parametric statistic. Korean Journal of Anesthesiology, 68(6), 540-546.

Kotler, P., \& Keller, K. L. (2007). Marketing management. Grada Publishing.

Kuščer, K., \& Mihalič, T. (2019). Residents' attitudes towards overtourism from the perspective of tourism impacts and cooperation - The case of Ljubljana. Sustainability, 11(6), 1823. https://doi.org/10.339o/su11061823

Lai, I. K. W., \& Hitchcock, M. (2015). Importance-perfor- mance analysis in tourism: A framework for researchers. Tourism Management, 48(C), 242-267.

Levenburg, N. M., \& Magal, S. R. (2004). Applying importance-performance analysis to evaluate e-business strategies among small firms. E-Service, 3(3), 29-48.

Martilla, J. A., \& James, J. C. (1977). Importance-performance analysis. Journal of Marketing, 41(1), 77-79.

Matulik, R. (2019, July 24). Masový a nezvládnutý turismus devastuje populární destinace. Český rozhlas. https://plus .rozhlas.cz/masovy-a-nezvladnuty-turismus-devastujepopularni-destinace-staci-jet-jinam-8039752

Matzler, K., Sauerwein, E., \& Heischmidt, K. (2003). Importance-performance analysis revisited: The role of the factor structure of customer satisfaction. The Service Industries Journal, 23(2), 112-129.

Middleton, V. T. C., \& Clarke, J. (2001). Marketing in travel and tourism. Butterworth-Heinemann.

Milano, C., Cheer, J. M., \& Novelli, M. (2018, July 18). Overtourism: A growing global problem. The Conversation. https://theconversation.com/overtourism-a-growing -global-problem-100029

Milošević, S., Penezić, N., Mišković, I., Škrbić, I., \& Katić, I. (2016). The significance of tourists' satisfaction at the destinations. In 23rd Biennial International Congress, Tourism \& Hospitality Industry 2016 (THI2016), Trends and Challenges, Opatija, Croatia, 28-29 April 2016 (pp. 219-231). University of Rijeka.

Mok, C., Sparks, B., \& Kadampully, J. (2013). Service quality management in hospitality, tourism, and leisure. Routledge.

Namberger, P., Jackisch, S., Schmude, J., \& Karl, M. (2019). Overcrowding, overtourism and local level disturbance: How much can Munich handle? Tourism Planning \& Development, 16(4), 452-472.

Oh, H. (2001). Revisiting importance-performance analysis. Tourism Management, 22(6), 617-627.

Pásková, M. (2009). Udržitelnost rozvoje cestovního ruchu. Gaudeamus Univerzita Hradec Králové.

Politis, Y., Litos, C., Grigoroudis, E., \& Moustakis, V. S. (2009). A business excellence model for the hotel sector: Implementation to high/class Greek hotels. Benchmarking: An International Journal, 16(4), 462-483.

Puczko, L., \& Ratz, T. (200o). Tourist and resident perceptions of the physical impacts of tourism at Lake Balaton, Hungary: Issues for sustainable tourism management. Journal of Sustainable Tourism, 8(6), 458-478.

Ramakrishnan, R., \& Usha, R. (2016). A new rational IPA and application to cruise tourism. Annals of Tourism Research, 61(C), 264-267. 
Rasoolimanesh, S. M., Roldán, J. L., Jaafar, M., \& Ramayah, T. (2017). Factors influencing residents' perceptions toward tourism development: Differences across rural and urban world heritage sites. Journal of Travel Research, 56(6), 760-775.

Rašovská, I., Kubíčková, M., \& Ryglová, K. (2020). Importance-performance analysis approach to destination management. Tourism Economics. https://doi.org/10 $.1177 / 1354816620903913$

Ryglová, K., Rašovská, I., \& Šácha, J. (2017). Rural tourism: Evaluating the quality of destination. European Countryside, 9(4), 769-788.

Ryglová, K., Vajcnerová, I., Sácha, J., \& Stojarova, S. (2015). The quality as a competitive factor of the destination. Procedia: Economics and Finance, 34, 550-556.

Sampson, S. E., \& Showalter, M. J. (1999). The performanceimportance response function: Observations and implications. Service Industries Journal, 19(3), 1-25.

Simpson, F. (1999). Tourist impact in the historic centre of Prague: Resident and visitor perceptions of the historic built environment. Geographical Journal, 165(2), 173-183.

Stylidis, D., Sit, J., \& Biran, A. (2016). An exploratory study of residents' perception of place image: The case of Kavala. Journal of Travel Research, 55(5), 659-674.

Su, L., Swanson, S. R., \& Chen, X. (2016). The effects of perceived service quality on repurchase intentions and subjective well-being of Chinese tourists. Tourism Management, 52, 82-95.

Tonge, J., \& Moore, S. A. (2007). Importance-satisfaction analysis for marine-park hinterlands: A Western Australian case study. Tourism Management, 28(3), 768-776.

Unw To. (N.d.a). About us. https://www.unwto.org/about -us

UN w To. (N.d.b). Sustainable development. https://www .unwto.org/sustainable-development

Wang, X., Li, X. R., Zhen, F., \& Zhang, J. (2016). How smart is your tourist attraction? Measuring tourist preferences of smart tourism attractions via a FCEM-AHP and IPA approach. Tourism Management, 54, 309-320.

Weaver, P. A., Weber, K., \& McCleary, K. W. (2007). Destination evaluation: The role of previous travel experience and trip characteristics. Journal of Travel Research, 45(3), 333-344.

Wong, M., Hideki, N., \& George, P. (2011). The use of importance-performance analysis (IPA) in evaluating Japan's egovernment services. Journal of Theoretical and Applied Electronic Commerce Research, 6(2), 17-30.

Zelenka, J., \& Pásková, M. (2012). Výkladový slovník cestovního ruchu. Linde Praha.

\section{Appendix}

The following factors were researched:

1. Natural attractions (the conditions of natural character - for instance, climate, hydrological and morphological circumstances, flora, fauna, water surfaces, caves, natural reservations).

2. Cultural and social attractions (for instance, castles, chateaus, galleries, museums, technical sights, religious monuments, historical city centres).

3. Accommodation (variety, structure, and level of accommodation facilities).

4. Food (variety, structure, and level of boarding facilities).

5. Social and experiential events (for example, concerts, festivals, folk, sports and other events, local markets, seasonal gastronomical events such as wine harvests).

6. Availability of transportation to the destination (the accessibility of the destination, transport infrastructure, the frequency of transport links, distances between stops).

7. Local transportation (the possibilities of motorized and non-motorized transport around the destination, the conditions and equipment of the means of transport, the frequency and distances of stops from attractions, taxis, ski lifts, cableways and so on).

8. Availability and quality of the information in the destination (tourist information centres, maps, promotional materials, orientation boards, internet - Wi$\mathrm{Fi})$.

9. Information and communication prior to arrival (the promotion and distribution of the destination offer, available and user-friendly unified web portal with topical destination offer that enables online reservations, links to related websites, information on social networks and so on).

10. Friendly acceptance by the locals (atmosphere at the destination, friendly relationships with visitors).

11. Image of the destination.

12. Level of prices of services and goods at the destination (the prices of consumer goods and services at the destination).

13. Level of personnel quality in tourism services - which means in accommodation and boarding services, information centres, transportation, guides and so on (their professionalism, empathy, willingness, reliability, credibility, opening hours, the effort to meet individual requirements of a client).

14. Sense of security (crime, terrorism, natural disasters, diseases, rescue and health system, the security 
of sights, the security of pedestrians or cyclists, safe background/attractions for children).

15. Destination cleanliness (natural environment, air, water for swimming, public toilets, enough waste bins, the cleanliness and maintenance of sights, the cleanliness of hospitality facilities).

16. Overcrowding of the destination (high concentration of visitors decreasing the quality of their stay, the capacity congestion of infrastructure, for example, car parks).

17. The uniqueness of the destination (the uniqueness of the destination, local products, the differentiation of competitive offers, pre-prepared service packets, products of the destination for various target segments, service certification).
18. Additional infrastructure (for example, sports equipment rental shops, cycle paths, cross country ski trails, hippo trails, aqua parks, playgrounds, entertainment centres, climbing centres, cash dispensers, background for motorists, cyclists, children).

19. Respecting sustainable development of the destination (the concordance of infrastructure construction with the natural environment of the destination, cultural heritage protection - for instance, protection of historical buildings, folklore and regional cuisine, natural environment protection, ecological economy, local inhabitants and business involvement).

20. Certification of accommodation and food services. 